\title{
Electro-oxidation of Ethanol on Carbon Supported PtSn and PtSnNi Catalysts
}

\author{
Nur Hidayati ${ }^{*}$, Keith Scott ${ }^{2}$ \\ ${ }^{1}$ Department of Chemical Engineering, Universitas Muhammadiyah Surakarta \\ Jl. A. Yani Tromol Pos 1 Pabelan Kartasura, Surakarta, Indonesia \\ ${ }^{2}$ School of Chemical Engineering and Advanced Materials, Newcastle University \\ Newcastle upon Tyne, NE1 7RU, UK
}

Received: 10 ${ }^{\text {th }}$ November 2015; Revised: 1 ${ }^{\text {st }}$ February 2016; Accepted: 1 ${ }^{\text {st }}$ February 2016

\begin{abstract}
Even though platinum is known as an active electro-catalyst for ethanol oxidation at low temperatures $\left(<100{ }^{\circ} \mathrm{C}\right)$, choosing the electrode material for ethanol electro-oxidation is a crucial issue. It is due to its property which easily poisoned by a strong adsorbed species such as CO. PtSn-based electro-catalysts have been identified as better catalysts for ethanol electro-oxidation. The third material is supposed to improve binary catalysts performance. This work presents a study of the ethanol electro-oxidation on carbon supported Pt-Sn and Pt-Sn-Ni catalysts. These catalysts were prepared by alcohol reduction. Nano-particles with diameters between 2.5-5.0 $\mathrm{nm}$ were obtained. The peak of (220) crystalline face centred cubic (fcc) Pt phase for PtSn and PtSnNi alloys was repositioned due to the presence of Sn and/or Ni in the alloy. Furthermore, the modification of Pt with Sn and SnNi improved ethanol and CO electro-oxidation. Copyright $@ 2016$ BCREC GROUP. All rights reserved
\end{abstract}

Abstract

Keywords: Direct Ethanol Fuel Cells; ethanol electro-oxidation catalysts; PtSn/C; PtSnNi/C

How to Cite: Hidayati, N., Scott, K. (2016). Electro-oxidation of Ethanol on Carbon Supported PtSn and PtSnNi Catalysts. Bulletin of Chemical Reaction Engineering \& Catalysis, 11 (1): 10-20. (doi:10.9767/bcrec.11.1.399.10-20)

Permalink/DOI: http://dx.doi.org/10.9767/bcrec.11.1.399.10-20

\section{Introduction}

It is well known that Pt is a good electrocatalyst for oxidation but does not exhibit high activity for ethanol electro-oxidation [1, 2]. Research has thus focused on the use of alloy catalysts to improve the electro-activity of $\mathrm{Pt}$ [3-8]. Metals such as Sn have been identified as suitable materials to form alloys with $\mathrm{Pt}$ for ethanol electro-oxidation in acid solutions [810]. However, the performance of $\mathrm{PtSn} / \mathrm{C}$ catalyst depends on the preparation procedures, the

* Corresponding Author.

E-mail: nur.hidayati@ums.ac.id (N. Hidayati)
Pt:Sn atomic ratio and catalyst structure [2, 11-15]. Zhou et al. [16] observed that the optimum Sn content altered the fuel cell maximum density at different temperature.

There are some different preparation methods. Recently, a number of researchers have investigated the ethanol oxidation on carbon supported PtSn catalysts prepared by impregnation reduction method [17], Bonneman's method [13], polyol process [2] and modified borohydride reduction [15]. Nevertheless, the effect of Sn content was not clear. The group of Lamy et al., Zhou et al., and Kim et al. have found the optimum composition of $\mathrm{Sn}$ in the range of $10-20 \%[13,17], 33-40 \%[2,18,19]$. and $20-33 \%$ [14], respectively. 
The third material is supposed to improve binary catalysts. Spinace et al. [20] have studied the activity of ethanol electro-oxidation on $\mathrm{PtSn} / \mathrm{C}$ and $\mathrm{PtSnNi} / \mathrm{C}$ catalysts. It was found that the $\mathrm{PtSnNi} / \mathrm{C}$ catalyst gives higher current values and superior stability than $\mathrm{PtSn} / \mathrm{C}$. However, further investigation is needed in order to find the optimum composition of $\mathrm{Pt}: \mathrm{Sn}: \mathrm{Ni}$ and its application in the DEFCs.

This work presents a study of the ethanol electro-oxidation on carbon supported Pt-Sn and Pt-Sn-Ni catalysts, and their applications as anode catalysts in a single DEFC. These catalysts were prepared by alcohol reduction followed by X-ray diffraction (XRD) and energy dispersive analysis of X-ray (EDAX) characterisations. Electrochemical measurements including linear sweep voltammetry (LSV), chronoamperometry and carbon monoxide stripping voltammetry were also carried out to evaluate the electroactivity of catalysts towards ethanol oxidation.

\section{Experimental}

\subsection{Catalysts Preparation}

Carbon supported $\mathrm{PtSn}$ with various atomic ratio and $\mathrm{PtSnNi}$ catalysts were prepared by the polyol process [2]. $\mathrm{H}_{2} \mathrm{PtCl}_{6} 6 \mathrm{H}_{2} \mathrm{O}$, $\mathrm{SnCl}_{2} .2 \mathrm{H}_{2} \mathrm{O}$ and $\mathrm{NiCl}_{2} .6 \mathrm{H}_{2} \mathrm{O}$ from Aldrich were used as precursors. All samples were supported on Vulcan XC-72R carbon black (Cabot Corp., $\left.\mathrm{S}_{\text {BET }}=237 \mathrm{~m}^{2} \mathrm{~g}^{-1}\right)$. The precursors were dissolved in ethylene glycol $(10 \% \mathrm{v} / \mathrm{v}$ of water) and stirred for 30 minutes. The $\mathrm{pH}$ of solution was adjusted between 12 and 13 with sodium hydroxide then heated at temperature of $130{ }^{\circ} \mathrm{C}$ for about 2 hours to complete the reduction process. The carbon support was mixed with a few drops of ethylene glycol solution and ultrasonicated to form slurry (called as carbon slurry). The carbon slurry was added drop-wise to the metals precursor solution and mixed for about $4 \mathrm{~h}$ then cooled down to at room temperature. The solution was filtered, washed and finally dried at $80{ }^{\circ} \mathrm{C}$ for about $10 \mathrm{~h}$ in a vacuum oven.

\subsection{Physicochemical Characterisation}

Physicochemical characterisation was carried out to obtain information regarding the morphology and structure of the catalysts. Catalyst compositions were confirmed by Energy dispersive X-ray analysis (EDAX) performed using a Rontec attachment, a JEOL 5300LV scanning electron microscope.
Particle sizes were determined by Transmission Electron Microscopy (TEM) using a Philips CM 100 Compustage (FEI) with an AMT CCD camera (Deben). The samples for characterisation were prepared by mixing the catalyst with water and ultrasonicated for a few minutes. A small drop of this mixture containing the catalysts was deposited onto a copper grid covered with a membrane and left to dry. Histograms of particle sizes distribution were constructed using the images obtained from approximately 100 particles. The average particle size of catalysts was calculated from the size distribution.

X-ray diffraction (XRD) was used to analyse the crystallites structure of catalysts. The XRD data were recorded with a PAN analytical X'pert Pro MPD (multipurpose diffractometer) using $\mathrm{Cu}$ Ka radiation $(\mathrm{l}=1.54056 \mathrm{~A})$ and fitted with an X'celerator. Radiation was generated at $40 \mathrm{KV}$ and $40 \mathrm{~mA}$. The $2 \theta$ angular regions between $10^{\circ}$ and $90^{\circ}$ were explored at a nominal step size of $0.033^{\circ} 2 \theta$ and time per step of 100 seconds. The scan was carried out in continuous mode.

\subsection{Electrochemical Characterisation}

Electrochemical measurements carried out were cyclic voltammetry (CV), linear sweep voltammetry (LSV) and chronoamperometry. Measurements were performed using a PC controlled Voltalab PGZ100 potentiostat, and a conventional three electrode cell. The working electrode was a very thin layer of Nafion ${ }^{\circledR}$ bonded-catalyst deposited on the tip of a glassy carbon rod (BASi MF-2012) with an area of $0.07 \mathrm{~cm}^{2}$.

The catalyst layer was prepared from a catalyst ink, obtained by ultrasonicating the Ptbased catalyst, 5 wt.\% Nafion or PBI solution and ethanol. The solvent was then evaporated in an oven. The quantity of electro-catalysts on the working electrode was $0.005 \mathrm{mg}$.

The electrochemical tests were performed in a two-compartment glass cell. A lugin capillary probe was fitted to the working electrode chamber for electrode potential measurements and control of potential. The volumes of the cell chambers were $200 \mathrm{~cm}^{3}(\mathrm{~mL})$. A water jacket linked to an external heating bath was employed to perform tests at a controlled temperature. A Pt mesh and an $\mathrm{Ag} / \mathrm{AgCl}$ electrode were used as the counter and reference electrode, respectively.

Before CV and chronoamperometry measurements, the solution was purged with nitrogen and stirred for twenty minutes to remove oxygen from the solution. The potential was cy- 
cled to remove any contaminants at scan rates of $50 \mathrm{mV} \mathrm{s}^{-1}$. CV and LSV data were recorded at a $5 \mathrm{mV} \mathrm{s}^{-1}$ scan rate and chronoamperometry was performed at $500 \mathrm{mV}$.

The CO electro-oxidation was carried out in $0.5 \mathrm{~mol} \mathrm{dm}^{-3}$ (M) $\mathrm{H}_{2} \mathrm{SO}_{4}$ solution which was sparged with nitrogen. After a reproducible cyclic voltammogram was obtained, the electrode was held at a potential of $100 \mathrm{mV}$ vs RHE. Meanwhile, carbon monoxide was introduced into the solution for about 15 minutes. Unabsorbed $\mathrm{CO}$ was removed by sparging nitrogen into the solution for about 30 minutes. Potentials were then swept at $20 \mathrm{mV} \mathrm{s}^{-1}$ and followed by recording the $\mathrm{CO}$ stripping voltammogram. All potentials were reported on the standard hydrogen scale.

\section{Results and Discussion}

EDAX analysis was employed to estimate the nominal composition of the prepared catalysts. The measured Pt:Sn and Pt:Sn:Ni atomic ratios of the prepared catalysts were slightly different from its catalyst solution compositions (Table 1).

Figure 1 shows the typical TEM images and histogram of the particle sizes distribution of
$\mathrm{PtSn} / \mathrm{C}$ and $\mathrm{PtSnNi} / \mathrm{C}$ catalysts. The particle sizes were found to be in the range of 1 to 10 $\mathrm{nm}$ with mean diameters of 3-5 nm. Meanwhile, Figures 2 and 3 show XRD patterns of the carbon supported $\mathrm{PtSn}$ and $\mathrm{PtSnNi}$ which are compared to the commercial carbon supported Pt (E-TEK), in which the characteristic peak of crystalline face centred cubic (fcc) $\mathrm{Pt}$ phase at (111), (200), (220) and (311) planes appear at the corresponding diffraction angles. The diffraction peak at $20-25^{\circ}$ observed in all the diffraction patterns of the carbon supported catalysts was attributed to the (002) plane of the hexagonal structure of Vulcan XC-72R carbon black. There were no obvious peaks for $\mathrm{Sn}$, $\mathrm{Ni}$ or their oxides; however their presence cannot be discounted. They might be present in small amounts or even transformed into an amorphous form. The calculated alloying degree of Sn in the PtSn (Table 2) observed the present of the amorphous form or Sn oxides in the catalysts. For bimetallic catalysts, only ca. $3-16 \%$ of Sn atoms were alloyed in the PtSn alloy formation. In addition, the commercial $\mathrm{PtSn} / \mathrm{C}$ has higher alloyed of $\mathrm{Sn}$ about $40 \%$ in comparison to its home-made $\mathrm{PtSn} / \mathrm{C}$ catalysts.

The (220) reflection of $\mathrm{Pt}$ was referred to estimate the average particle size according to

Table 1. The atomic compositions and metals loading of all catalysts (* determined by EDAX)

\begin{tabular}{ccccc}
\hline \multirow{2}{*}{ Catalysts } & \multicolumn{3}{c}{ Atomic ratio * } & \multirow{2}{*}{ All metals loading* (\%) } \\
\cline { 2 - 4 } & $\mathrm{Pt}$ & $\mathrm{Sn}$ & $\mathrm{Ni}$ & 20 \\
\hline $\mathrm{Pt} / \mathrm{C}$ & & & & 33.5 \\
$\mathrm{Pt}_{3} \mathrm{Sn}_{1} / \mathrm{C}$ & 2.70 & 1.0 & - & 19.4 \\
$\mathrm{Pt}_{2} \mathrm{Sn}_{1} / \mathrm{C}$ & 1.95 & 1.0 & - & 40.3 \\
$\mathrm{Pt}_{1} \mathrm{Sn}_{1} / \mathrm{C}$ & 1.20 & 1.0 & - & 62.9 \\
$\mathrm{Pt}_{4} \mathrm{Sn}_{4} \mathrm{Ni}_{1} / \mathrm{C}$ & 4.10 & 3.9 & 1.0 & \\
\hline
\end{tabular}

Table 2. The average particle sizes, $2 \theta_{\max }$ position, lattice parameter and alloying degree of all catalysts

\begin{tabular}{cccccc}
\hline \multirow{2}{*}{ Catalysts } & \multicolumn{2}{c}{ Average particle size $(\mathrm{nm})$} & \multirow{2}{2}{\begin{tabular}{c}
$\theta_{\text {max }}$ \\
\cline { 2 - 3 }$\left({ }^{\circ}\right)$
\end{tabular}} & $\begin{array}{c}\text { Lattice parameter } \\
(\AA)\end{array}$ & $\begin{array}{c}\text { Alloying } \\
\text { Degree } \\
(\%)\end{array}$ \\
\hline $\mathrm{Pt} / \mathrm{C}$ & $3.0 \pm 0.8$ & 3.1 & 67.23 & 3.9355 & - \\
$\mathrm{Pt}_{3} \mathrm{Sn}_{1} / \mathrm{C}$ & $4.3 \pm 1.4$ & 3.9 & 67.14 & 3.9397 & 3.3 \\
$\mathrm{Pt}_{2} \mathrm{Sn}_{1} / \mathrm{C}$ & $4.7 \pm 1.8$ & 4.9 & 66.71 & 3.9627 & 10.9 \\
$\mathrm{Pt}_{1} \mathrm{Sn}_{1} / \mathrm{C}$ & $3.3 \pm 0.8$ & 2.6 & 66.67 & 3.9648 & 16.3 \\
$\mathrm{Pt}_{4} \mathrm{Sn}_{4} \mathrm{Ni}_{1} / \mathrm{C}$ & $4.1 \pm 1.4$ & 3.4 & 68.29 & 3.8513 & - \\
\hline
\end{tabular}



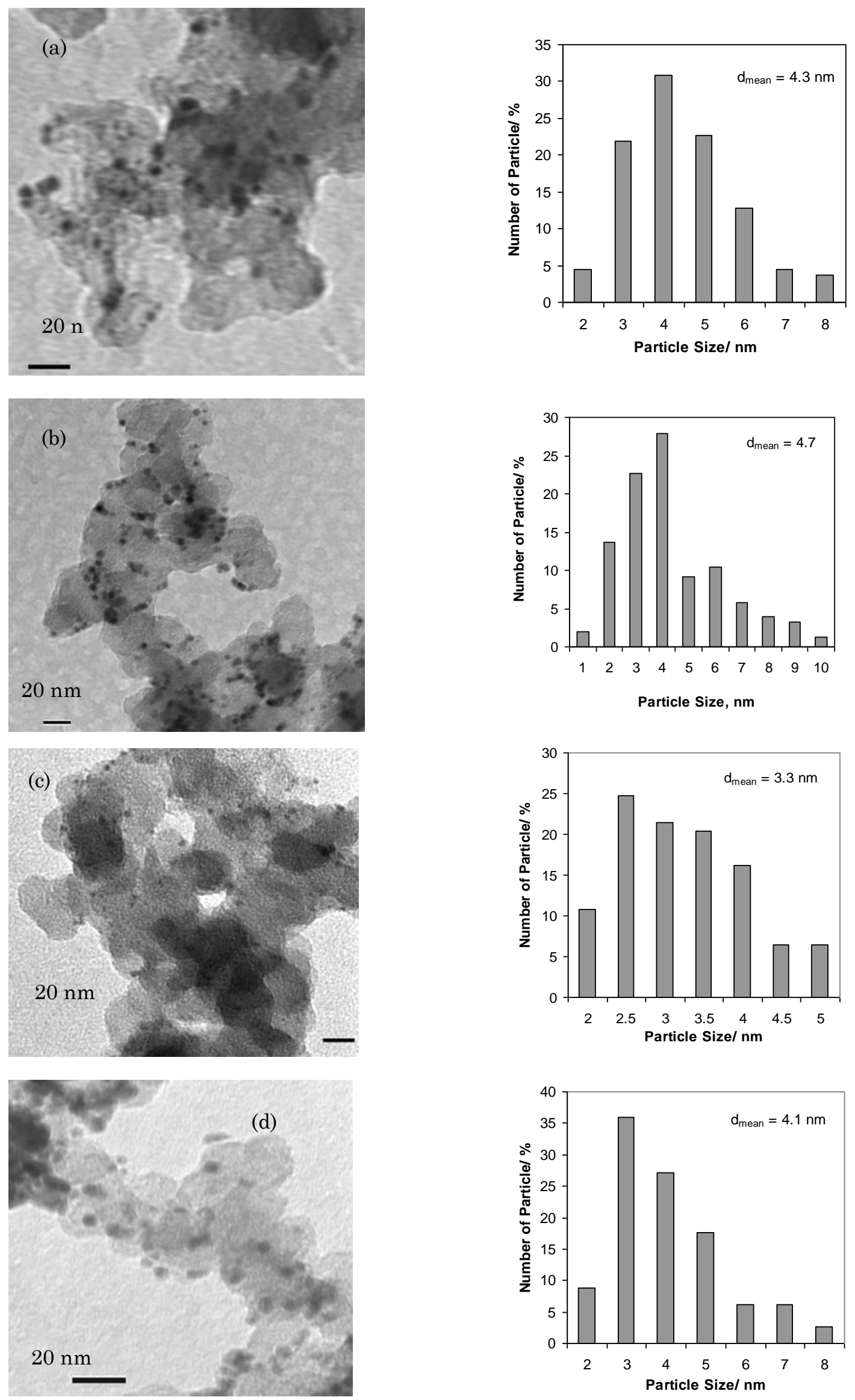

Figure 1. TEM images and histograms of catalysts: (a) $\mathrm{Pt}_{3} \mathrm{Sn}_{1} / \mathrm{C}$, (b) $\mathrm{Pt}_{2} \mathrm{Sn}_{1} / \mathrm{C}$, (c) $\mathrm{Pt}_{1} \mathrm{Sn}_{1} / \mathrm{C}$, (d) $\mathrm{Pt}_{4} \mathrm{Sn}_{4} \mathrm{Ni}_{1} / \mathrm{C}$. 
the Scherrer formula and lattice parameter [21]. The diffraction peak of Pt (220) was used as the reference to avoid possible disturbances from carbon black [22]. The average particle size and lattice parameter calculated from XRD patterns are summarised in Table 2. Calculated average particle sizes are in the range of 3-5 $\mathrm{nm}$ which are similar to those obtained using TEM measurement.

The XRD patterns reported in Figures 2 and 3 , show remarkable differences between the carbon supported Pt and PtSn-based catalysts in their average particle sizes and the peak position of the (220) planes. The diffraction peak of the $\mathrm{PtSn} / \mathrm{C}$ and $\mathrm{PtSnNi} / \mathrm{C}$ catalysts shifted into opposite directions in comparison with $\mathrm{Pt} / \mathrm{C}$ catalyst. In the case of $\mathrm{PtSn} / \mathrm{C}$ catalysts, the addition of $\mathrm{Sn}$ to $\mathrm{Pt}$ increased the lattice parameter of the Pt (fcc) crystal structure as indicated by the shift to lower $2 \theta$ values in the (220) diffraction peaks. The shift might be attributed to alloy formation between $\mathrm{Pt}$ and $\mathrm{Sn}$ [23]. With increasing Sn content, there was a greater shift in lattice parameter away from pure Pt. These results were in agreement with recent data for $\mathrm{PtSn} / \mathrm{C}$ catalysts using a borohydride reduction method [14]. The presence of $\mathrm{Ni}$ in Pt-Sn, on the contrary to Sn alone, shifted the diffraction peak to higher $2 \theta$ value. The shift is an indication of the reduction in the lattice parameter.

\subsection{Electrochemical Characterisation}

Figure 4 shows the cyclic voltamograms of carbon supported $\mathrm{Pt}$ and home-made electrocatalysts in the absence of ethanol at room temperature. All CVs reported after a stable and consistent scans were achieved. The scan rate was measured to be $5 \mathrm{mV} \mathrm{s}^{-1}$. The current was normalised to $\mathrm{mA}$ per $\mathrm{mg} \mathrm{Pt}$ loading. The cou-

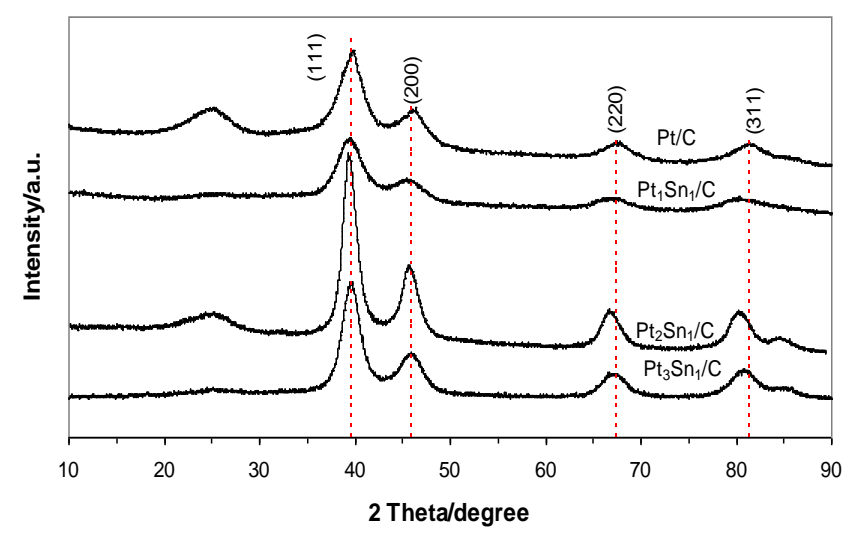

Figure 2. XRD patterns of Pt-Sn catalysts compared to $\mathrm{Pt} / \mathrm{C}$ commercial catalyst lombic charge of hydrogen adsorption region obtained after subtracting charge contributed from the double layer region was used to calculate specific electrochemical active surface areas (ESAH). The EASH data for all catalysts are summarised in Table 3. The $\mathrm{Pt} / \mathrm{C}$ and $\mathrm{Pt}$ alloyed catalysts have similar active surface area, which were approximately $70-86 \mathrm{~m}^{2} \mathrm{~g}^{-1}$ of Pt loading.

It shows that the $\mathrm{CVs}$ of PtSn electrocatalysts did not have a well-defined hydrogen region compared to that of pure Pt. As observed from the XRD result, platinum alloying by Sn or $\mathrm{SnNi}$ has altered the crystalline lattice parameter which may affect the adsorption and desorption of hydrogen. The Pt alloy generally exhibited larger current densities in the double layer region, which may be related to the presence of $\mathrm{SnO}_{2}[23,24]$. Furthermore, the voltammograms show that alloyed Pt catalysts assign the formation of oxygen-containing species through water adsorption starting at around $0.4 \mathrm{~V}$. These potentials are much lower than that experienced on a Pt/C catalyst, i.e. at above $0.7 \mathrm{~V}$ [25].

CO stripping voltammetry was studied at a scan rate of $20 \mathrm{mV} \mathrm{s}^{-1}$ and in $0.5 \mathrm{~mol} \mathrm{dm}^{-3} \mathrm{H}_{2} \mathrm{SO}_{4}$

Table 3. The active surface area (ESA) of catalysts calculated from cyclic and $\mathrm{CO}$ stripping voltammograms

\begin{tabular}{ccc}
\hline Catalysts & $\begin{array}{c}\mathrm{ESA}_{\mathrm{H}} \\
\left(\mathrm{m}^{2} \mathrm{~g}^{-1} \mathrm{Pt}\right.\end{array}$ & $\begin{array}{c}\mathrm{ESA} \mathrm{CO}_{\mathrm{co}} \\
\left(\mathrm{m}^{2} \mathrm{~g}^{-1} \mathrm{Pt}\right)\end{array}$ \\
\hline $\mathrm{Pt} / \mathrm{C}$ & 77.9 & 67.3 \\
$\mathrm{Pt}_{3} \mathrm{Sn}_{1} / \mathrm{C}$ & 71.3 & 60.0 \\
$\mathrm{Pt}_{2} \mathrm{Sn}_{1} / \mathrm{C}$ & 84.0 & 64.4 \\
$\mathrm{Pt}_{1} \mathrm{Sn}_{1} / \mathrm{C}$ & 86.1 & 65.8 \\
$\mathrm{Pt}_{4} \mathrm{Sn}_{4} \mathrm{Ni}_{1} / \mathrm{C}$ & 85.0 & 79.0 \\
\hline
\end{tabular}

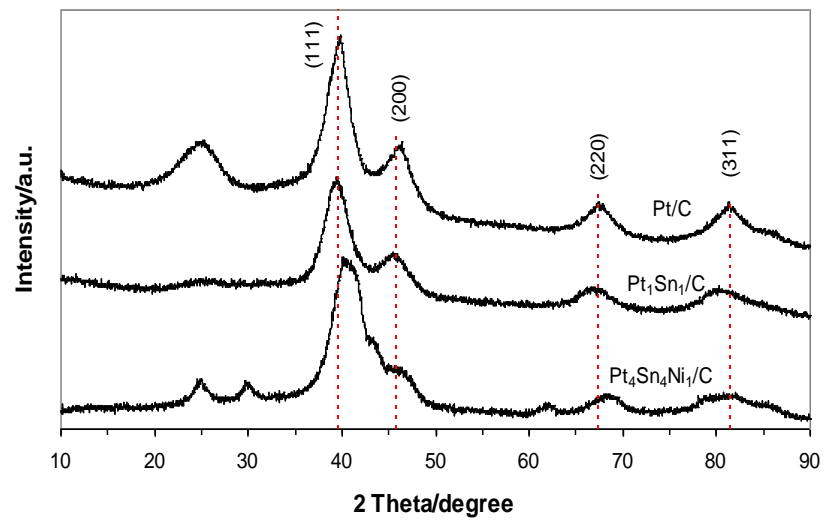

Figure 3. XRD patterns of ternary $\mathrm{PtSnNi} / \mathrm{C}$ and $\mathrm{Pt} / \mathrm{C}$ commercial catalysts 
to estimate the active surface area (ESACO) of the alloyed Pt electro-catalysts and to obtain electrochemical information regarding the Ptbased catalysts surface. The ESACO of the electro-catalysts were calculated using Equation (1).

$$
\mathrm{ESA}_{\mathrm{CO}}=\frac{Q_{C O}}{420}
$$

where $Q_{C O}$ is the charge of the $\mathrm{CO}$ desorption in micro coulomb normalised with the mass of $\mathrm{Pt}$ loading on the electrode, and 420 is the adsorption charge for a monolayer of $\mathrm{CO}$ on the catalyst in $\mu \mathrm{C} \mathrm{cm}^{-2}$.

The ESACO of the Pt-based electrocatalysts are given in Table 3, and their CO stripping voltammograms are presented in Figure 5. The ESACO (normalised by gram of Pt) increased with increasing Sn content in the PtSn alloy catalysts. The active area was observed to be around 60, 64 and $66 \mathrm{~m}^{2} \mathrm{~g}^{-1}$ (Pt loading) for PtSn catalysts with atomic ratio of 3:1, 2:1 and $1: 1$, respectively. The $\mathrm{Pt}_{1} \mathrm{Sn}_{1} / \mathrm{C}$ catalyst with the highest Sn content exhibited the highest ESACO. This result, interestingly, has similar trend with the lattice parameter. The ESACO value and lattice parameter of $\mathrm{Pt}$ crystalline in PtSn catalysts increase as the Sn content increases.

The effect of the adsorbed $\mathrm{CO}$ on the catalysts surface was to remove the peak associated with hydrogen activity and to produce a $\mathrm{CO}$ oxidation peak in the first positive sweep. The CO oxidation has produced a sharp peak at around $0.8 \mathrm{~V}$ and the onset potential was ca.

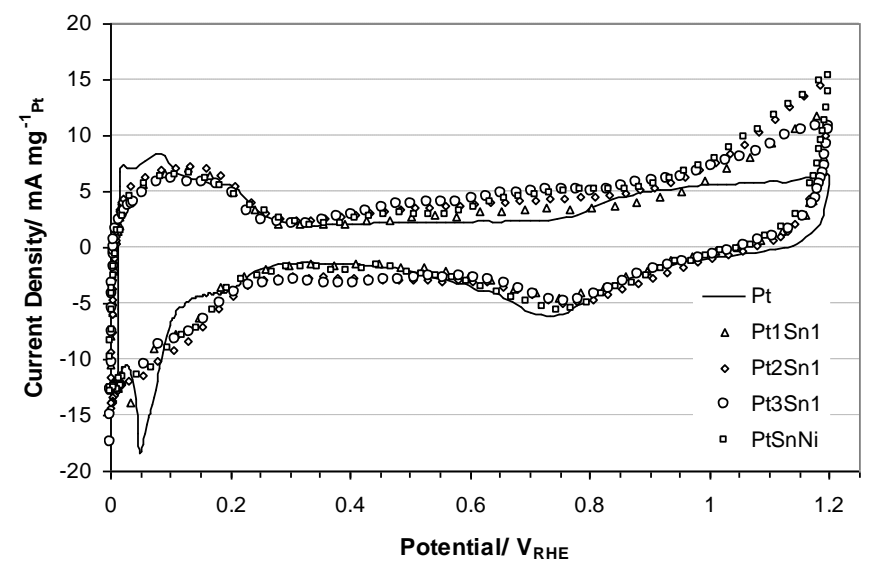

Figure 4. The cyclic voltammogram of the $\mathrm{PtSn} / \mathrm{C}$ and $\mathrm{Pt} / \mathrm{C}$ catalysts in $0.5 \mathrm{~mol} \mathrm{dm}^{-3}$ of $\mathrm{H}_{2} \mathrm{SO}_{4}$ solution, at scan rate of $5 \mathrm{mV} \mathrm{s}{ }^{-1}$ and $25^{\circ} \mathrm{C}$. (1) $\mathrm{Pt} / \mathrm{C}$,
(2) $\mathrm{Pt}_{1} \mathrm{Sn}_{1} / \mathrm{C}$,
(3) $\mathrm{Pt}_{2} \mathrm{Sn}_{1} / \mathrm{C}$,
(4) $\mathrm{Pt}_{3} \mathrm{Sn}_{1} / \mathrm{C}$, (5)

$0.7 \mathrm{~V}$. The cyclic voltammogram for $\mathrm{Pt} / \mathrm{C}$ catalyst, showed oxygenated species generated by water oxidation at above $0.7 \mathrm{~V}$ and carbon monoxide electro-oxidation on pure Pt catalyst consequently started at this point. Generally, alloyed Pt catalysts exhibited lower onset potentials for $\mathrm{CO}$ oxidation than pure platinum, i.e. around $0.4 \mathrm{~V}$, as water oxidation occurred at the same value. Moreover, for bimetallic catalysts, the $\mathrm{CO}$ oxidation peak was broader as well as lower.

The shift of the $\mathrm{CO}$ oxidation onset potential to lower values for the alloyed $\mathrm{PtSn} / \mathrm{C}$ compared to the $\mathrm{Pt} / \mathrm{C}$ catalyst is in agreement with works reported previously [26-28]. The higher $\mathrm{CO}$ oxidation activity at lower potential on the alloyed Pt catalysts may be due to a more effective bifunctional mechanism at lower potential. The ability of $\mathrm{Sn}$ to promote the oxidation of adsorbed $\mathrm{CO}$ on the $\mathrm{Pt}$ sites was by adsorbing $\mathrm{OH} \cdot$ species produced from water disassociation $[26,29,30]$ as described in Equation (2).

$$
\mathrm{Pt}-(\mathrm{CO})_{\mathrm{ad}}+\mathrm{Sn}-(\mathrm{OH})_{\mathrm{ad}} \rightarrow \mathrm{Pt}-\mathrm{Sn}+\mathrm{CO}_{2}+\mathrm{H}^{+}+\mathrm{e}^{-}
$$

Other groups also reported that the $\mathrm{Sn}$ in alloys had an electronic effect, due to the $\mathrm{Pt}$ lattice expansion by incorporation of Sn atom [14,30,31]. The electronic or ligand effect may change the electronic properties of $\mathrm{Pt}$ sites as a consequence of the bonding between $\mathrm{Pt}$ and $\mathrm{Sn}$. The expansion of $\mathrm{Pt}$ lattice parameter may cause a change in the charge transfer from Sn atoms to neighbouring $\mathrm{Pt}$ atoms and

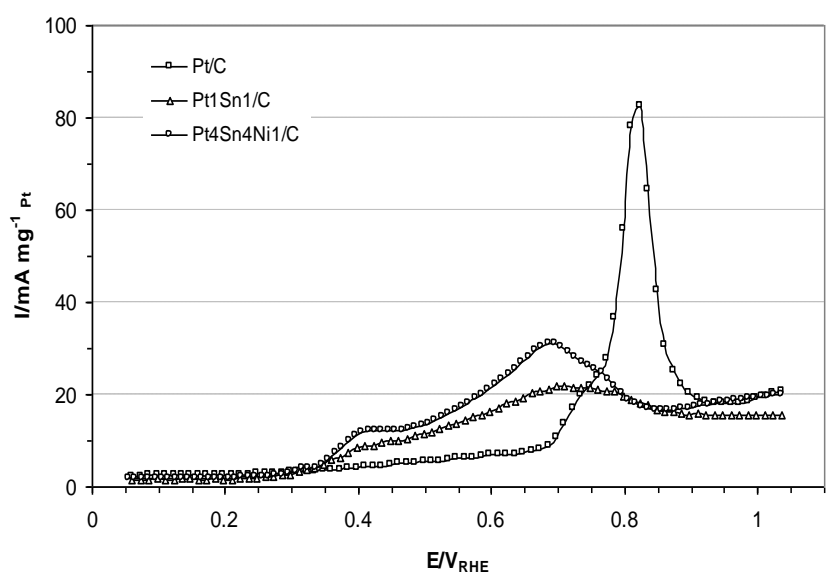

Figure 5. Voltammograms for $\mathrm{CO}$ electrooxidation on $\mathrm{Pt} / \mathrm{C}, \mathrm{Pt}_{1} \mathrm{Sn}_{1} / \mathrm{C}$ and $\mathrm{Pt}_{4} \mathrm{Sn}_{4} \mathrm{Ni}_{1} / \mathrm{C}$ catalysts, $0.5 \mathrm{~mol} \mathrm{dm}^{-3} \mathrm{H}_{2} \mathrm{SO}_{4}$ at room temperature, $20 \mathrm{mV} \mathrm{s}^{-1}$ of scan rate 
decrease in the $\mathrm{Pt} 4 \mathrm{f}$ binding energy. This electronic effect weakens adsorbed $\mathrm{CO}$ on the surface of Pt sites [14].

The presence of $\mathrm{Ni}$ in the PtSn catalyst increased slightly the active area from 66 to 79 $\mathrm{m}^{2} \mathrm{~g}^{-1}$ (see Table 2) in which determined from the CO oxidation. From previous studies, Park et al. [32] reported that $\mathrm{Ni}$ shifted the $\mathrm{Pt} 4 \mathrm{f}$ binding energy for PtNi and PtRuNi to lower values than that for Pt. Electron transfer might contribute to enhance $\mathrm{CO}$ oxidation. Other research has reported that $\mathrm{Ni}$ enhanced PtRu catalyst during $\mathrm{CO}$, methanol and ethanol oxidation [32, 33]. The Pt-Ni electronic interaction dominated the promoting effect of $\mathrm{Ni}$ on absorbed $\mathrm{CO}$ oxidation by weakening the Pt-CO bonding energy rather than the bifunctional mechanism.

The presence of a second or third metal added to $\mathrm{Pt}$ is necessary to improve catalytic activity for ethanol oxidation. Especially in an acid environment, $\mathrm{Pt}$ alone has limited ability to cleave the C-C bond and oxidize the adsorbed CO, which is considered to be disadvantages in ethanol oxidation [8]. Figures 6 and 7 show linear sweep voltammograms for the binary and ternary electro-catalysts for ethanol oxidation.

The electro-oxidation of ethanol on the $\mathrm{Pt} / \mathrm{C}$ catalyst started at $0.45 \mathrm{~V}$, whilst the addition $\mathrm{Sn}$ to $\mathrm{Pt} / \mathrm{C}$ catalyst shifted the onset potentials to lower values (ca. 0.25-0.4 V). Interestingly, the Sn content significantly influenced the onset potential of ethanol electro-oxidation. The better electroactivity, i.e. lowest onset potential, was obtained for the $\mathrm{PtSn} / \mathrm{C}$ catalysts with an atomic ratio of $1: 1(0.25 \mathrm{~V})$, followed by those with ratios of $2: 1(0.27 \mathrm{~V})$ and $3: 1(0.40$ $\mathrm{V})$, respectively. In comparison, the commercial

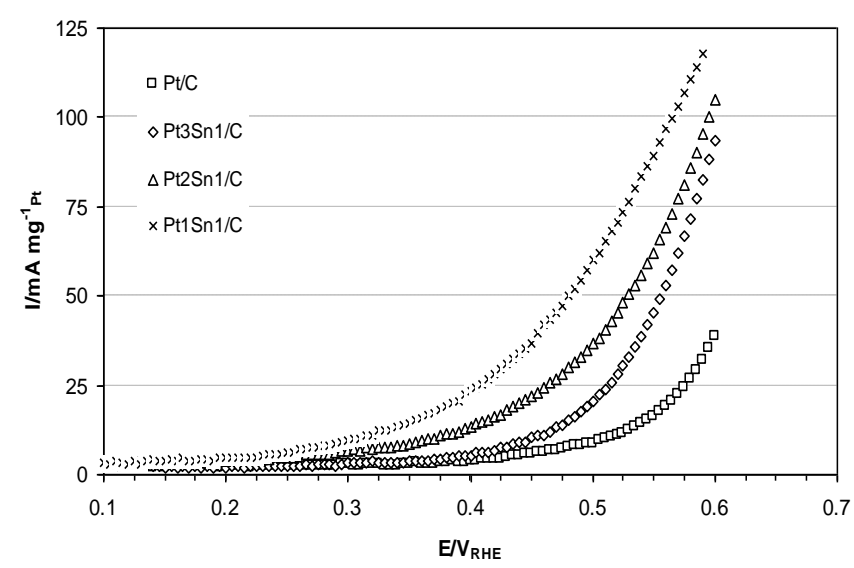

Figure 6. Linear sweep voltammograms of ethanol electro-oxidation on $\mathrm{PtSn} / \mathrm{C}$ and $\mathrm{Pt} / \mathrm{C}$ catalysts, $1 \mathrm{~mol} \mathrm{dm}^{-3}$ ethanol and $0.5 \mathrm{~mol} \mathrm{dm}^{-3} \mathrm{H}_{2} \mathrm{SO}_{4}$ solution, scan rate of $2 \mathrm{mV} \mathrm{s}^{-1}$ at $25^{\circ} \mathrm{C}$.
$\mathrm{PtSn} / \mathrm{C}$ showed the onset potential of $0.18 \mathrm{~V}$ recorded at a scan rate of $5 \mathrm{mV} \mathrm{s}^{-1}$ and the temperature of $30{ }^{\circ} \mathrm{C}$. The present of alloyed $\mathrm{PtSn}$ or Sn oxides provide oxygenated species at lower potential. As soon as $\mathrm{Sn}-\mathrm{OH}$ was formed, the adsorbed $\mathrm{CO}$ and other intermediates were oxidised which are called bifunctional mechanism. Due to its lower degree of alloying, Sn oxides may act mainly as an active sites at lower potential for dissociative adsorption of water.

Spinacé et al. [20] prepared catalysts with a similar method and results, whilst Lamy et al. [13] showed a superior ethanol electrooxidation performance using $\mathrm{PtSn} / \mathrm{C}$ catalyst electro-catalysts prepared by the Bönneman method, with atomic ratio of 9:1. With employing a thermal decomposition of a polymeric precursor, PtSn (60:40) gave the best activity for ethanol electro-oxidation for catalysts deposited on a Ti substrate [34]. Thus the preparation procedure strongly affects the electrocatalytic activity of $\mathrm{PtSn} / \mathrm{C}$ catalysts for ethanol oxidation.

Figure 6 presents the LSV data for ethanol electro-oxidation on carbon supported $\mathrm{PtSn}$ and $\mathrm{PtSnNi}$ catalysts in acidic medium at temperature of 25 and $60{ }^{\circ} \mathrm{C}$. In comparison to the Pt1Sn1/C catalyst, the addition of $\mathrm{Ni}$ to Pt-Sn did not change the onset potential of ethanol electro-oxidation, however enhanced the current density at a potential above $0.5 \mathrm{~V}$. Similar results were obtained by Spinacé et al. [20] for $\mathrm{PtSn} / \mathrm{C}$ and $\mathrm{PtSnNi}$ catalysts at room temperature with atomic ratios of $1: 1$ and 5:4:1, respectively. As reported that temperature did not alter the rds of ethanol electrooxidation on all observed catalysts, even though it lowered the onset potential and in-

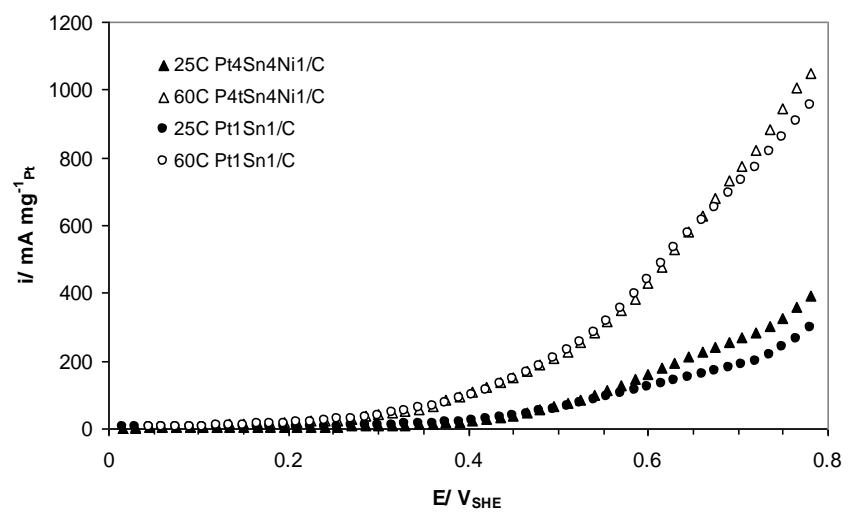

Figure 7. Linear sweep voltammograms of ethanol electro-oxidation on $\mathrm{Pt}_{1} \mathrm{Sn}_{1} / \mathrm{C}$ and $\mathrm{Pt}_{4} \mathrm{Sn}_{4} \mathrm{Ni}_{1} / \mathrm{C}$ catalysts. $1 \mathrm{~mol} \mathrm{dm}^{-3}$ ethanol and $0.5 \mathrm{~mol} \mathrm{dm}^{-3} \mathrm{H}_{2} \mathrm{SO}_{4}$ solutions, scan rate of $2 \mathrm{mV}$ $\mathrm{s}^{-1}$ at 25 and $60{ }^{\circ} \mathrm{C}$ 
creased mass activity, i.e. current density. Therefore, the effect of temperature in detail was not further investigated.

As discussed previously, the presence of $\mathrm{Ni}$ in the PtSn catalyst enhanced $\mathrm{CO}$ oxidation by weakening Pt-CO bond (ligand effect). When Pt site was able to provide the $\mathrm{OH}$ species at a high potential $(>0.5 \mathrm{~V})$, it was noticed that the weaker adsorbed $\mathrm{CO}$ was oxidised easily. An increased active area also contributed to provide wider catalyst surface in order to adsorb ethanol.

The current density of ethanol electrooxidation on $\mathrm{PtSn} / \mathrm{C}$ at $0.55 \mathrm{~V}$ and temperature of $25{ }^{\circ} \mathrm{C}$ was about $89 \mathrm{~mA} \mathrm{mg}{ }^{-1}$, whilst that of on $\mathrm{PtSnNi} / \mathrm{C}$ was about $10 \mathrm{~mA} \mathrm{mg-1}$ higher. At temperature of $60{ }^{\circ} \mathrm{C}$, the current density of ethanol electro-oxidation on $\mathrm{PtSnNi} / \mathrm{C}$ was about $40 \mathrm{~mA} \mathrm{mg}-1$ higher than that of on $\mathrm{PtSn} / \mathrm{C}$ at $0.7 \mathrm{~V}$.

The corresponding Tafel plots are shown in Figure 8 and a further comparison of ethanol electro-oxidation activity is shown in the chrono-amperometry data (Figure 9). Each measurement was performed over 5 minutes to approach steady state conditions. It can be seen that the current density of ethanol electrooxidation on $\mathrm{Pt}_{4} \mathrm{Sn}_{4} \mathrm{Ni}_{1} / \mathrm{C}$ catalyst was slightly higher than that for $\mathrm{Pt}_{1} \mathrm{Sn}_{1} / \mathrm{C}$ catalyst; in agreement with the LSV data. The current densities were found to be 13 and $15 \mathrm{~mA} \mathrm{mg}^{-1} \mathrm{Pt}$ for $\mathrm{Pt}_{1} \mathrm{Sn}_{1} / \mathrm{C}$ and $\mathrm{Pt}_{4} \mathrm{Sn}_{4} \mathrm{Ni}_{1} / \mathrm{C}$ at $0.4 \mathrm{~V}$. Whilst the ethanol electro-oxidation current density on $\mathrm{Pt}_{4} \mathrm{Sn}_{4} \mathrm{Ni}_{1} / \mathrm{C}$ was measured to be 9 and $62 \mathrm{~mA}$ $\mathrm{mg}^{-1} \mathrm{Pt}$ at 0.5 and $0.6 \mathrm{~V}$, respectively.
Kinetic parameters were determined from Tafel plots obtained from LSV and chronoamperometry data. Tafel slopes and exchange current densities for all catalysts are listed in Table 4. Tafel slopes for $\mathrm{Pt}_{1} \mathrm{Sn}_{1} / \mathrm{C}$ and $\mathrm{Pt}_{4} \mathrm{Sn}_{4} \mathrm{Ni}_{1} / \mathrm{C}$ catalysts were found to be similar at around $90-100 \mathrm{mV} \mathrm{dec}-1$, whilst those for $\mathrm{Pt}_{2} \mathrm{Sn}_{1} / \mathrm{C}, \mathrm{Pt}_{3} \mathrm{Sn}_{1} / \mathrm{C}$ and $\mathrm{Pt} / \mathrm{C}$ catalysts were 85 , 72 and $55 \mathrm{mV} \mathrm{dec}^{-1}$, respectively. The close Tafel slope values of $\mathrm{PtSn} / \mathrm{C}$ catalysts indicate a similar mechanism of ethanol electrooxidation on those catalysts.

However, the Tafel slope of catalyst with high Sn loading $\left(\mathrm{Pt}_{1} \mathrm{Sn}_{1} / \mathrm{C}\right)$ is quite far with that of $\mathrm{Pt} / \mathrm{C}$, thus the rds may change. The difference in Tafel slopes should be related to the number of electron associated with the overall reaction. As mentioned previously, ethanol electro-oxidation on $\mathrm{Pt}$ or Pt alloyed catalysts included several complex reactions. The adsorption of ethanol occurs on $\mathrm{Pt}$, whereas alloyed metals such Sn most likely offer $\mathrm{OH}$ - adsorption at lower potential to remove the adsorbed $\mathrm{CO}$ or to convert the intermediate into acetic acid. The mean electron number of 2 and 4 correspond mainly to the ethanol electro-oxidation into acetaldehyde and acetic acid formation, respectively. Rousseou and coworker [35] investigated product distribution in DEFCs test with different anode catalysts, i.e. $\mathrm{Pt} / \mathrm{C}, \mathrm{PtSn} / \mathrm{C}$ and $\mathrm{PtSnRu} / \mathrm{C}$. The addition of $\mathrm{Sn}$ to $\mathrm{Pt}$ favoured the formation acetic acid over acetaldehyde, in comparison to the pure $\mathrm{Pt}$, but the yield of $\mathrm{CO}_{2}$ was detected to be doubled with a $\mathrm{Pt} / \mathrm{C}$ than with a $\mathrm{PtSn} / \mathrm{C}$ catalyst. Those results are in agreement with Ta-

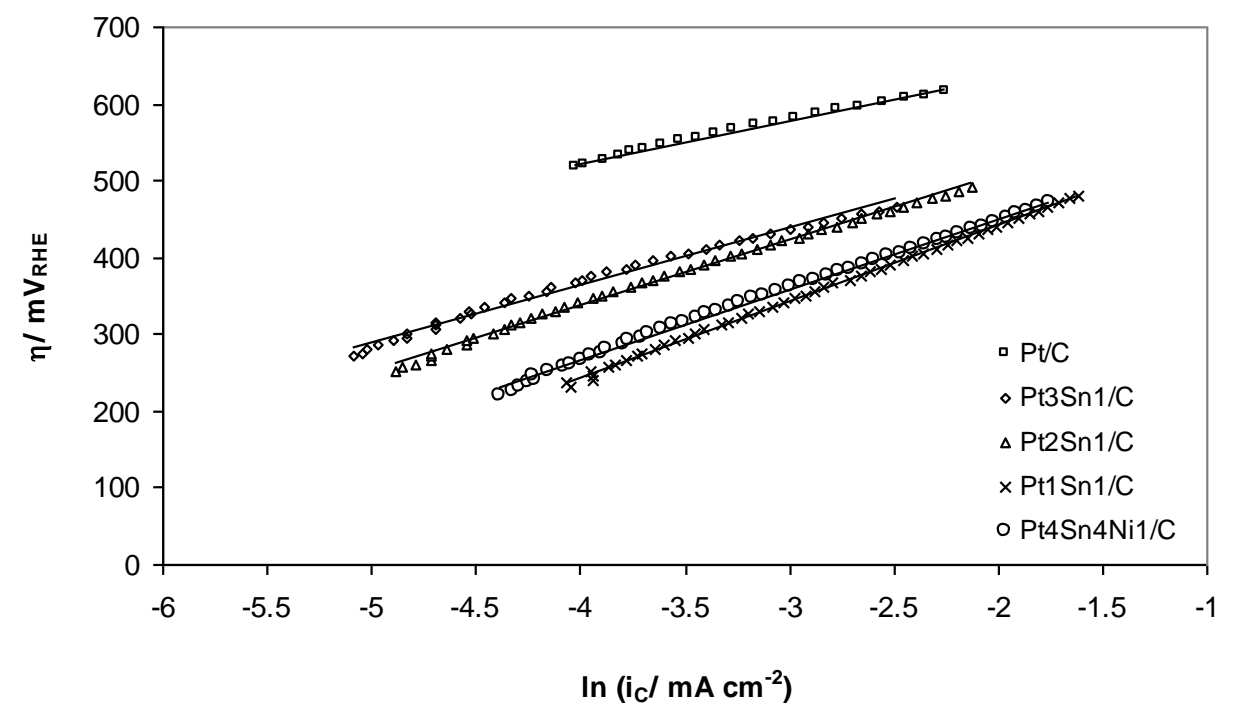

Figure 8. Tafel plots of ethanol electro-oxidation on $\mathrm{PtSnNi} / \mathrm{C}, \mathrm{PtSn} / \mathrm{C}$ and $\mathrm{Pt} / \mathrm{C}$ catalysts in $1 \mathrm{~mol}$ $\mathrm{dm}^{-3}$ ethanol and $0.5 \mathrm{~mol} \mathrm{dm}^{-3} \mathrm{H}_{2} \mathrm{SO}_{4}$ solution. The current density was normalised to the active surface area $\left(\mathrm{ESA}_{\mathrm{CO}}\right)$ of the respective catalysts 
fel slopes that are obtained from this work for a high loading $\mathrm{Sn}$ catalyst. The $\mathrm{Pt} / \mathrm{C}$ catalyst shows having the lowest slope which indicates that the overall reaction on $\mathrm{Pt} / \mathrm{C}$ has generated more electrons in comparison to that on $\mathrm{Pt}$ alloyed catalysts. Hence, the selectivity towards the formation of acetic acid, acetaldehyde and $\mathrm{CO}_{2}$ correlate to the number of electron generated by the total reaction and rate determining step in the mechanism reaction.

Exchange current densities of $\mathrm{Pt} / \mathrm{C}, \mathrm{Pt}_{3} \mathrm{Sn}_{1} / \mathrm{C}$ $\mathrm{Pt}_{2} \mathrm{Sn}_{1} / \mathrm{C} \mathrm{Pt}_{1} \mathrm{Sn}_{1} / \mathrm{C}$ and $\mathrm{Pt}_{4} \mathrm{Sn}_{4} \mathrm{Ni} / \mathrm{C}$ were about $1.3 \times 10^{-6}, \quad 1.1 \times 10^{-4}, \quad 3.5 \times 10^{-4}, \quad 1.5 \times 10^{-3}, \quad$ and $1.0 \times 10^{-3} \mathrm{~mA} \mathrm{~cm}^{-2}$, respectively. Those values were normalised by the active surface area (ESACO). Exchange current densities for PtSn catalysts increase with the increase of Sn content. In this work, the highest exchange current density was obtained for the $\mathrm{Pt}_{1} \mathrm{Sn}_{1} / \mathrm{C}$ catalyst. This reflects the rate of ethanol electrooxidation on the surface of $\mathrm{PtSn} / \mathrm{C}$ catalyst is faster than that on others. However, the addition of Ni to PtSn slightly reduces the exchange current density. Zhu et al. [36] reported the exchange current densities of $\mathrm{PtSn} / \mathrm{C}$ catalysts of $5.38,2.52$ and $0.102 \mathrm{~mA} \mathrm{~cm}^{-2}$ prepared with different methods that were obtained from anode polarisation curve at $90{ }^{\circ} \mathrm{C}$ for $\mathrm{PtSn} / \mathrm{C}-\mathrm{B}$, $\mathrm{PtSn} / \mathrm{C}-\mathrm{EG}$ and $\mathrm{PtSnO}_{2} / \mathrm{C}$, respectively. Exchange current densities were however based on the cross-section of the electrode. The PtSn/C-B which had the highest alloying degree displayed enhancement of activity for ethanol electro-oxidation.

\section{Conclusions}

Carbon supported PtSn with different atomic ratio and $\mathrm{PtSnNi}$ were prepared by a polyol method. Nano-particles with diameters between 2.5-5.0 nm were obtained. According to the XRD results, the peak of (220) crystalline face centred cubic (fcc) Pt phase for PtSn and $\mathrm{PtSnNi}$ alloys was repositioned due to the presence of $\mathrm{Sn}$ and/or $\mathrm{Ni}$ in the alloy. The modification of structural and electronic features was observed as the shift of lattice parameter might facilitate a better adsorbed $\mathrm{CO}$ oxidation. Furthermore, the modification of $\mathrm{Pt}$ with $\mathrm{Sn}$ and $\mathrm{SnNi}$ improved ethanol and $\mathrm{CO}$ electro-oxidation. According to the bifunctional mechanism, the present of Sn oxides provided oxygenated species at lower potentials in comparison to pure Pt. The observed

Table 4. Tafel slope and exchange current density values of all catalysts

\begin{tabular}{ccc}
\hline Catalysts & $\begin{array}{c}\text { Tafel slopes } \\
\left(\mathrm{mV} \mathrm{dec}^{-1}\right)\end{array}$ & $\begin{array}{c}\text { Exchange cur- } \\
\text { rent densities } \\
\left(\mathrm{mA} \mathrm{cm}^{-2}\right)\end{array}$ \\
\hline $\mathrm{Pt} / \mathrm{C}$ & 55 & $1.310^{-6}$ \\
$\mathrm{Pt}_{3} \mathrm{Sn}_{1} / \mathrm{C}$ & 72 & $1.110^{-4}$ \\
$\mathrm{Pt}_{2} \mathrm{Sn}_{1} / \mathrm{C}$ & 85 & $3.510^{-4}$ \\
$\mathrm{Pt}_{1} \mathrm{Sn}_{1} / \mathrm{C}$ & 99 & $1.510^{-3}$ \\
$\mathrm{Pt}_{4} \mathrm{Sn}_{4} \mathrm{Ni}_{1} / \mathrm{C}$ & 92 & $1.010^{-3}$ \\
\hline
\end{tabular}

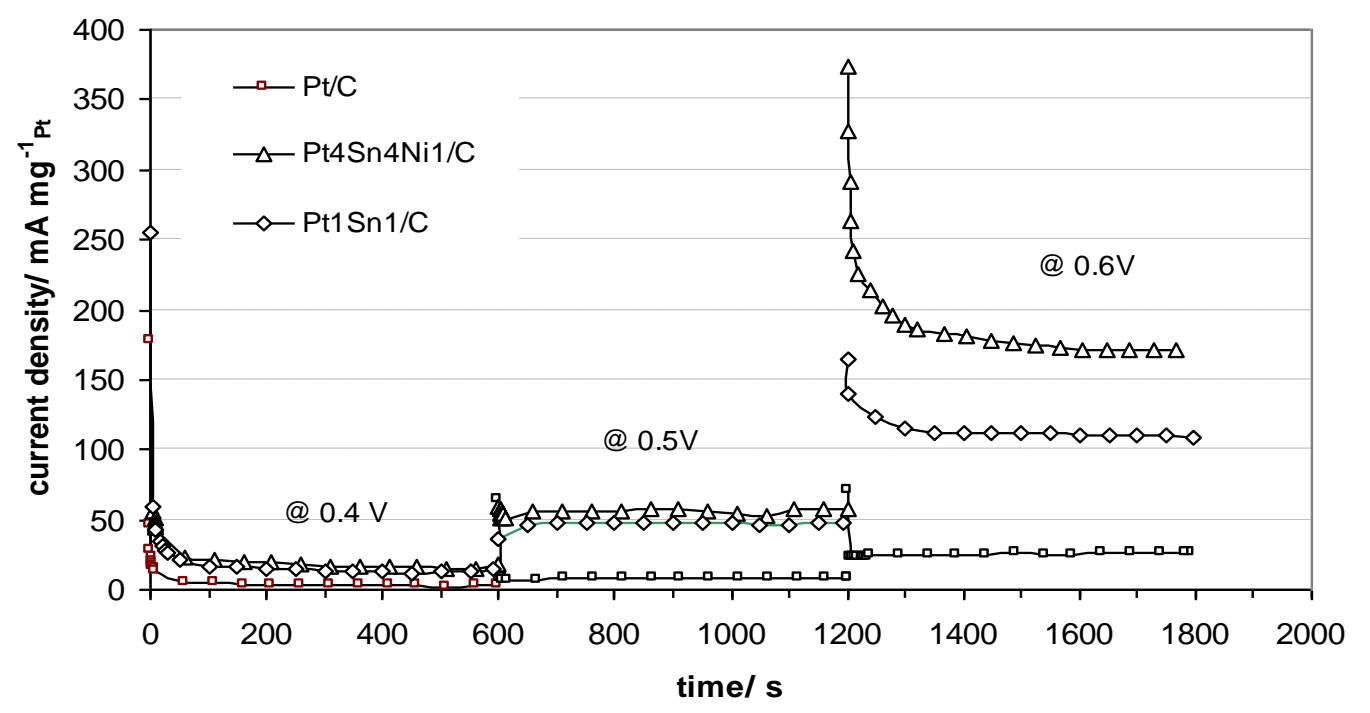

Figure 9. Chronoamperometric curves of ethanol electro-oxidation for $\mathrm{Pt}_{1} \mathrm{Sn}_{1} / \mathrm{C}$ and $\mathrm{Pt}_{4} \mathrm{Sn}_{4} \mathrm{Ni}_{1} / \mathrm{C}$ catalysts. $1 \mathrm{~mol} \mathrm{dm}^{-3}$ ethanol and $0.5 \mathrm{~mol} \mathrm{dm}^{-3} \mathrm{H}_{2} \mathrm{SO}_{4}$ at room temperature 
Tafel slopes suggested that bi and tri-metallic Pt-based catalysts with high Sn loading have altered the rate determining step of mechanism which the overall reaction on those catalysts produced fewer electrons than that on pure Pt. However, the exchange current density of ethanol oxidation reaction on Pt-based catalysts was accelerated significantly by factor of 1001000. In general, $\mathrm{PtSnNi} / \mathrm{C}$ catalysts showed a better electrocatalytic activity than $\mathrm{PtSn} / \mathrm{C}$ catalysts in half-cell tests.

\section{Acknowledgments}

This work was performed with scholarship support from Schlumberger Foundation with the program of Faculty for the Future.

\section{References}

[1] Lamy, C., Belgsir, E.M., Léger, J.M. (2001). Electrocatalytic oxidation of aliphatic alcohols: Application to the direct alcohol fuel cell (DAFC). J. Appl. Electrochem., 31: 799809.

[2] Zhou, W., Zhou, Z., Song S, Li. W., Sun, G., Tsiakaras, P., Xin, Q. (2003). Pt based anode catalysts for direct ethanol fuel cells. Appl. Catal. B. Environ., 46: 273-285.

[3] Delime, F., Leger, J.M., Lamy, C. (1999). Enhancement of the electrooxidation of ethanol on a Pt-PEM electrode modified by tin. Part I: Half cell study. $J$ Appl Electrochem, 29: 1249-1254.

[4] Camara, G., de Lima, R., Iwasita, T. (2004). Catalysis of ethanol electrooxidation by PtRu: the influence of catalyst composition. Electrochem. Commun., 6: 812-815.

[5] Liu, Z., Ling, X.Y., Su, X., Lee, J.Y., Gan, L.M. (2005). Preparation and characterization of $\mathrm{Pt} / \mathrm{C}$ and $\mathrm{PtRu} / \mathrm{C}$ electrocatalysts for direct ethanol fuel cells. J. Power Sources, 149: 1-7.

[6] Mann, J., Yao, N., Bocarsly, A.B. (2006). Characterization and analysis of new catalysts for a direct ethanol fuel cell. Langmuir, 22: 10432-10436.

[7] Sen Gupta, S., Datta, J.A. (2006). Comparative study on ethanol oxidation behavior at $\mathrm{Pt}$ and $\mathrm{PtRh}$ electrodeposits. J. Electroanal. Chem, 594: 65-72.

[8] Zhou, W.J., Li, W.Z., Song, S.Q., Zhou, Z.H., Jiang, L.H., Sun, G.Q., et al. (2004). Bi- and tri-metallic Pt-based anode catalysts for direct ethanol fuel cells. J .Power Sources, 131: 217-223.

[9] Song, S.Q., Zhou, W.J., Zhou, Z.H., Jiang, LH., Sun, G.Q., Xin, Q., et al. (2005). Direct ethanol PEM fuel cells: The case of platinum based anodes. Int. J. Hydrogen Energy, 30: 995-1001.

[10] Wang, H., Jusys, Z., Behm, R.J. (2006). Ethanol electro-oxidation on carbonsupported $\mathrm{Pt}, \mathrm{PtRu}$ and $\mathrm{Pt}_{3} \mathrm{Sn}$ catalysts: A quantitative DEMS study. J. Power Sources, 154: 351-359.

[11] Jiang, L., Colmenares, L., Jusys, Z., Sun, G.Q., Behm, R.J. (2007). Ethanol electrooxidation on novel carbon supported $\mathrm{Pt} / \mathrm{SnOx} / \mathrm{C}$ catalysts with varied $\mathrm{Pt}: \mathrm{Sn}$ ratio. Electrochim. Acta, 53: 377-389.

[12] Guo, Y., Zheng, Y., Huang, M., (2008). Enhanced activity of $\mathrm{PtSn} / \mathrm{C}$ anodic electrocatalyst prepared by formic acid reduction for direct ethanol fuel cells. Electrochim. Acta, 53: 3102-3108.

[13] Lamy, C., Rousseau, S., Belgsir, E.M., Coutanceau, C., Léger, J.M. (2004). Recent progress in the direct ethanol fuel cell: Development of new platinum-tin electrocatalysts. Electrochim. Acta, 49: 3901. 3908.

[14] Kim, J.H., Choi, S.M., Nam, S.H., Seo, M,H., Choi, S.H., Kim, W.B. (2008). Influence of Sn content on $\mathrm{PtSn} / \mathrm{C}$ catalysts for electrooxidation of $\mathrm{C}_{1}-\mathrm{C}_{3}$ alcohols: Synthesis, characterization, and electrocatalytic activity. Appl. Catal. B Environ., 82: 89-102.

[15] Colmati, F., Antolini, E., Gonzalez, E.R. (2007). Ethanol Oxidation on Carbon Supported Pt-Sn Electrocatalysts Prepared by Reduction with Formic Acid. $J$. Electrochem. Soc., 154: B39-B47.

[16] Zhou, W.J., Song, S.Q., Li, W.Z., Zhou, Z.H., Sun, G.Q., Xin, Q., et al. (2005). Direct ethanol fuel cells based on PtSn anodes: the effect of $\mathrm{Sn}$ content on the fuel cell performance. J. Power Sources. 140: 50-58.

[17] Vigier, F., Coutanceau, C., Hahn, F., Belgsir, E.M., Lamy, C. (2004). On the mechanism of ethanol electro-oxidation on $\mathrm{Pt}$ and $\mathrm{PtSn}$ catalysts: Electrochemical and in situ IR reflectance spectroscopy studies. $J$. Electroanal. Chem. 63: 81-89..

[18] Jiang, L., Sun, G., Zhou, Z., Zhou, W., Xin, Q. (2004). Preparation and characterization of $\mathrm{PtSn} / \mathrm{C}$ anode electrocatalysts for direct ethanol fuel cell. Catal. Today, 93-95: 665670.

[19] Jiang, L., Sun, G., Sun, S., Liu, J., Tang, S., $\mathrm{Li}, \mathrm{H}$, et al. (2005). Structure and chemical composition of supported $\mathrm{Pt}-\mathrm{Sn}$ electrocatalysts for ethanol oxidation. Electrochim. Acta , 50: 5384-5389.

[20] Spinacé, E. V., Linardi, M., Neto, A.O.(2005). Co-catalytic effect of nickel in the electro-oxidation of ethanol on binary 
Pt-Sn electrocatalysts. Electrochem. Commun., 7: 365-369.

[21] Eberhart, J. (1991). Structural and Chemical Analysis of Materials: X-ray, Electron and Neutron Diffraction, X-ray, Electron and Ion Spectrometry, Electron Microscopy. John Wiley and Sons Ltd.

[22] Mukerjee, S., Srinivasan, S., Soriaga, M.P., McBreen, J. (1995). Role of structural and electronic properties of $\mathrm{Pt}$ and $\mathrm{Pt}$ alloys on electrocatalysis of oxygen reduction. An in situ XANES and EXAFS investigation. $J$ Electrochem. Soc., 142: 1409-1422.

[23] Colmati, F., Antolini, E., Gonzalez, E.R. (2007). Ethanol oxidation on a carbonsupported $\mathrm{Pt}_{75} \mathrm{Sn}_{25}$ electrocatalyst prepared by reduction with formic acid: Effect of thermal treatment. Appl. Catal. B Environ., 73: 106-115.

[24] Spinacé, E., Neto, A., Linardi, M. (2004). Electro-oxidation of methanol and ethanol using $\mathrm{PtRu} / \mathrm{C}$ electrocatalysts prepared by spontaneous deposition of platinum on carbon-supported ruthenium nanoparticles. $J$. Power Sources, 129: 121-126.

[25] Lim, D-H., Choi, D-H., Lee, W-D., Park, D-R., Lee, H-I. (2007) The Effect of Sn Addition on a PtC Electrocatalyst Synthesized by Borohydride Reduction and Hydrothermal Treatment for a Low-Temperature Fuel Cell. Electrochem, Solid-State Lett., 10: B87-B90.

[26] Arenz, M., Stamenkovic, V., Blizanac, B., Mayrhofer, K, Markovic, N., Ross, P. (2005) Carbon-supported Pt-Sn electrocatalysts for the anodic oxidation of $\mathrm{H}_{2}, \mathrm{CO}$, and $\mathrm{H}_{2} / \mathrm{CO}$ mixtures.Part II: The structure-activity relationship. J. Catal., 232: 402-410.

[27] Lim, D-H., Choi, D-H., Lee, W-D., Lee, H-I. (2009) A new synthesis of a highly dispersed and $\mathrm{CO}$ tolerant $\mathrm{PtSn} / \mathrm{C}$ electrocatalyst for low-temperature fuel cell; its electrocatalytic activity and long-term durability. Appl. Catal. B Environ., 89: 484-493.

[28] Colmenares, L., Wang, H., Jusys, Z., Jiang, L., Yan, S., Sun, G.Q., et al. (2006). Ethanol oxidation on novel, carbon supported Pt alloy catalysts - Model studies under defined diffusion conditions. Electrochim. Acta, 52: 221-233.
[29] Hayden, B.E., Rendall, M.E., South, O. (2005). The stability and electro-oxidation of carbon monoxide on model electrocatalysts: Pt (111) $-\operatorname{Sn}(2 \times 2)$ and Pt(111)$\operatorname{Sn}(\sqrt{ } 3 \times \sqrt{ } 3) R 30^{\circ}$. J. Mol. Catal. A Chem., 228: 55-65.

[30] Gasteiger, H.A., Marković, N.M., Ross, P.N. (1996). Structural effects in electrocatalysis: electrooxidation of carbon monoxide on Pt3Sn single-crystal alloy surfaces. Catal. Letters, 36: 1-8.

[31] Tripković, A.V., Popović, K.D., Lović, J.D., Jovanović, V.M., Stevanović, S.I., Tripković, D.V., et al. (2009). Promotional effect of Snad on the ethanol oxidation at $\mathrm{Pt}_{3} \mathrm{Sn} / \mathrm{C}$ catalyst. Electrochem. Commun., 11: 10301033.

[32] Martínez-Huerta, M.V., Rojas, S, Gómez, D. L., Fuente, J.L, Terreros, P, Peña, M.A., Fierro, J.L.G. (2006). Effect of Ni addition over PtRu/C based electrocatalysts for fuel cell applications. Appl. Catal. B Environ., 69: $75-84$.

[33] Wang, Z-B., Yin, G-P., Zhang, J., Sun, Y-C., Shi, P-F. (2006). Investigation of ethanol electrooxidation on a Pt-Ru-Ni/C catalyst for a direct ethanol fuel cell. J. Power Sources, 160: $37-43$.

[34] Simões, F.C., dos Anjos, D.M., Vigier, F., Léger, J-M., Hahn, F., Coutanceau, C., et al. (2007). Electroactivity of tin modified platinum electrodes for ethanol electrooxidation. J. Power Sources, 167: 110.

[35] Rousseau, S., Coutanceau, C., Lamy, C., Léger, J-M. (2006). Direct ethanol fuel cell (DEFC): Electrical performances and reaction products distribution under operating conditions with different platinum-based anodes. J. Power Sources, 158: 18-24.

[36] Zhu, M., Sun, G., Xin, Q. (2009). Effect of alloying degree in $\mathrm{PtSn}$ catalyst on the catalytic behavior for ethanol electrooxidation. Electrochim. Acta, 54: 1511-1518.

\section{Selected and Revised Papers from The $2^{\text {nd }}$ International Conference on Chemical and Material Engi- neering 2015 (ICCME 2015) (29-20 September, 2015, Semarang, Indonesia) (http://econference.undip.ac.id/index.php/iccme/2015) after Peer-reviewed by ICCME 2015 and BCREC Reviewers}

